\title{
Renal markers in normal and hypertensive disorders of pregnancy in Indian women: a pilot study
}

\author{
Padma $\mathbf{Y}^{1^{*}}$, Aparna V B ${ }^{1}$, Kalpana $\mathbf{B}^{2}$, Ritika $\mathbf{V}^{1}$, Sudhakar $\mathbf{P} \mathbf{R}^{3}$ \\ ${ }^{1}$ Department of Biochemistry, ${ }^{2}$ Department of Obstetrics \& Gynecology, ${ }^{3}$ SHARE INDIA, Mediciti Institute of \\ Medical Sciences, Ghanpur village, Medchal Mandal, R.R. District, A.P. Hyderabad, India
}

Received: 30 August 2013

Accepted: 21 September 2013

*Correspondence:

Dr. Padma Yalamati,

E-mail: padma.md@ hotmail.com

(c) 2013 Padma $Y$ et al. This is an open-access article distributed under the terms of the Creative Commons Attribution Non-Commercial License, which permits unrestricted non-commercial use, distribution, and reproduction in any medium, provided the original work is properly cited.

\begin{abstract}
Background: Altered renal function is an essential component of the pathophysiological process in pre-eclampsia. Kidneys play an important role in the turnover of low molecular weight substances such as creatinine, uric acid and cystatin C. The present study was undertaken if these serum markers were characteristically altered in Indian pregnant women.

Methods: Serum levels were therefore determined in samples from 69 healthy women at term as well as in 27 samples of patients with Pregnancy induced hypertension (PIH) and in 20 patients with pre-eclampsia (PE).

Results: The levels of all three components were significantly higher in pre-eclamptic patients when compared to healthy controls with the mean \pm SD being $1.47 \pm 0.9$ vs. $1.06 \pm 0.2$ for cystatin $C, 0.95 \pm 0.2$ vs. $0.67 \pm 0.1$ for creatinine and $6.13 \pm 1.8$ vs. $4.28 \pm 1.1$ for uric acid respectively. In PIH cystatin C was significantly higher, $1.25 \pm$ 0.9 unlike creatinine, $0.67 \pm 0.14$ and uric acid, $4.30 \pm 1.0$. Receiver operating characteristic (ROC) plots demonstrated that the diagnostic accuracy of serum creatinine was superior to serum uric acid and serum cystatin $\mathrm{C}$ and serum uric acid was better than serum cystatin $\mathrm{C}$.

Conclusion: The maternal serum cystatin $\mathrm{C}$, creatinine and uric acid were all significantly elevated at the end of pregnancy in pre-eclampsia compared to those of healthy pregnant women. If this rise in the above markers during early pregnancy could predict the onset of PIH/PE, needs to be investigated.
\end{abstract}

Keywords: Pregnancy, Pregnancy induced hypertension, Pre-eclampsia, Cystatin C, Creatinine, Uric acid

\section{INTRODUCTION}

Pre-eclampsia is a complex and serious multi-system disorder of human pregnancy with a worldwide incidence of $5-7 \%$ and contributes significantly to maternal and perinatal morbidity and mortality. ${ }^{1,2}$ It is characterized by hypertension, proteinuria, and a generalized systemic vasoconstriction arising from circulatory disturbances secondary to a generalized endothelial dysfunction caused by inflammation. ${ }^{3}$ It is associated with defective endovascular trophoblastic invasion and insufficient remodeling of the uterine spiral arteries. ${ }^{4,5,6,7}$ Altered renal function is an essential component of the pathophysiological process in pre-eclampsia and close monitoring of renal function is important to ensure a timely delivery before serious renal damage occurs. The turnover of most of the low molecular weight substances such as creatinine, uric acid and cystatin $\mathrm{C}$ occur by the kidneys. Serum cystatin $\mathrm{C}$ is an endogenous marker of renal function. It is synthesized by all nucleated cells, produced at a constant rate and is exclusively eliminated from the circulation by glomerular filtration. Several studies have shown that serum cystatin $\mathrm{C}$ is a better marker for glomerular filtration rate than serum creatinine $^{8,9}$ particularly for individuals with small to moderate decrease in glomerular filtration rate, but only few studies of serum cystatin $\mathrm{C}$ in preeclampsia. ${ }^{10,11,12,13,14}$ However, there are no Indian studies 
to evaluate the relationship between serum cystatin $\mathrm{C}$ and pre-eclampsia. Hence, we would like to compare serum cystatin $\mathrm{C}$, creatinine and uric acid in normal and hypertensive disorders of pregnancy (PIH and PE). We hypothesize that a significant difference exists between the three renal markers in Indian pregnant women and also serum cystatin $\mathrm{C}$ is a better marker than serum creatinine and serum uric acid.

\section{METHODS}

Non fasting venous blood samples $(5 \mathrm{ml})$ were obtained from 69 healthy pregnant women at term (gestational age > 37 weeks) admitted to the labor ward at the Department Of Obstetrics \& Gynecology, Mediciti Institute Of Medical Sciences, Ghanpur, Ranga Reddy district, Andhra Pradesh, India. We included only healthy women without present or past history of hypertension, diabetes mellitus or clinically detected renal disease. We also acquired venous blood samples consecutively from 27 women with PIH and 20 preeclamptic women during the last trimester and got admitted for delivery. The criteria for diagnosing pregnancy induced hypertension and pre-eclampsia were based on the classification and diagnosis of the hypertensive disorders of pregnancy: statement from the international society for the study of hypertension in pregnancy (ISSHP). ${ }^{15}$ Pregnancy induced hypertension is defined as the development of hypertension (systolic blood pressure $\geq 140 \mathrm{mmHg}$ and or a diastolic blood pressure $\geq 90 \mathrm{mmHg}$ ) for the first time after mid pregnancy. Pre-eclampsia is defined as the development of hypertension (systolic blood pressure $\geq 140 \mathrm{mmHg}$ and or a diastolic blood pressure $\geq 90 \mathrm{mmHg}$ ) for the first time after mid pregnancy and urinary albumin excretion $1+(30 \mathrm{mg} / \mathrm{dl})$. These patients were also previously healthy without underlying renal disease, essential hypertension or diabetes. $10 \mathrm{ml}$ of early morning or random midstream urine was collected for analysis of urine proteins in all included participants. National Committee for Clinical Laboratory Standards (NCCLS) Guidelines 16, 17 was followed for sample collection, handling and processing. Serum creatinine and uric acid were analyzed immediately and the rest of the serum sample was appropriately labeled and stored at $-80^{\circ} \mathrm{C}$ until analysis for cystatin $\mathrm{C}$. Written informed consent was taken from all included participants. A study proforma was used to collect information on maternal sociodemographic, medical characteristics and delivery outcomes from the medical records.

\section{Measuring parameters- Maternal}

Height and weight of the patient at the time of admission for delivery were recorded using a calibrated measuring scale (SECA). The international society for the study of hypertension in pregnancy guidelines ${ }^{15}$ were followed for the measurement of blood pressure. Two measurements were taken 4 hours apart with an oscillometric digital sphygmomanometer (Model: Omron HEM-780N3).
Serum cystatin C was measured by a fully automated particle-enhanced immunonephelometric assay (N Latex cystatin C, Dade-Behring, Inc) in BN Pro-Spec nephelometer (Dade Behring, Inc, Deerfield, IL) according to the manufacturer's instructions. ${ }^{18}$ Polystyrene particles coated with specific antibodies to cystatin $\mathrm{C}$ are aggregated when mixed with samples containing human cystatin $\mathrm{C}$. These aggregates scatter a beam of light passed through the sample. The intensity of the scattered light is proportional to the amount of cystatin $\mathrm{C}$ in the sample. The result is evaluated by comparison with a standard of known concentration. The assay range is 0.23 to $8.0 \mathrm{mg} / \mathrm{L}$. The reference range for young, healthy persons is reported to be 0.53 to $0.95 \mathrm{mg} / \mathrm{L}$. The inter-assay coefficient of variation using controls level 1 and level 2 with assigned values of $0.92 \mathrm{mg} / \mathrm{L}$ and $1.8 \mathrm{mg} / \mathrm{L}$ were $2.2 \%$ and $1.0 \%$ respectively.

Serum creatinine was measured by modified kinetic Jaffe's reaction in Dade Behring-Dimension Xpand plus system using creatinine flex reagent cartridge according to the manufacturer's instructions. ${ }^{19,20}$ The assay range is $0-20 \mathrm{mg} / \mathrm{dl}$. The reference range for young, healthy females is reported to be $0.6-1.0 \mathrm{mg} / \mathrm{dl}$. The inter-assay coefficient of variation using Bio-Rad controls, level 1 and level 2 with assigned values of $2.16 \mathrm{mg} / \mathrm{dl}$ and 6.39 $\mathrm{mg} / \mathrm{dl}$ were $3.7 \%$ and $3.6 \%$ respectively.

Serum uric acid was measured by modified Uricase method in Dade Behring-Dimension Xpand plus system using uric acid flex reagent cartridge according to the manufacturer's instructions. ${ }^{21,22}$ The assay range is $0-20$ $\mathrm{mg} / \mathrm{dl}$. The reference range for young, healthy females is reported to be $2.6-6.0 \mathrm{mg} / \mathrm{dl}$. The inter-assay coefficient of variation using Bio-Rad controls, level 1 and level 2 with assigned values of $4.89 \mathrm{mg} / \mathrm{dl}$ and $9.03 \mathrm{mg} / \mathrm{dl}$ were $4.4 \%$ and $4.4 \%$ respectively.

An early morning or random mid-stream urine sample was collected for estimation of proteins. The concentration of total proteins in urine was measured by semi-quantitative dip stick method. ${ }^{23}$ Two readings of $1+$ (30 mg/dl) is diagnostic of pre-eclampsia.

\section{Measuring Parameters- Fetal}

The weight of the newborn was recorded by a digital weighing scale (SECA 354/364).

\section{Statistical Analysis}

The data was entered in a MS-Excel database. After cleaning and validation, the data was analyzed using the statistical program MedCalc for PC, version 12.7.0 (MedCalc Software, Belgium). The analysis was divided into two parts, initially descriptive analysis for intergroup comparisons and later to determine the cut - off levels for maximal sensitivity and specificity for serum levels of cystatin $\mathrm{C}$, creatinine and uric acid; Receiver operating characteristic (ROC) plots was used. Inter group comparisons were done using one way ANOVA and post 
hoc analysis by Student-Newman-Keuls test. A p - value of $<0.05$ was considered as statistically significant.

\section{RESULTS}

The height of 16 patients (11 controls, $4 \mathrm{PIH}, 1 \mathrm{PE})$ and the weight of 8 patients ( 7 controls, $1 \mathrm{PIH}$ ) were not available. There was no statistically significant difference in the mean values of maternal age, height, weight and parity status but we found a statistically significant difference $(p<0.05)$ in the mean values of BMI, systolic blood pressure, diastolic blood pressure, urinary proteins gestational age of delivery, mode of delivery, birth weight (Table: 1 ), serum cystatin $\mathrm{C}$, serum creatinine and serum uric acid between the three study groups (Table 2). Post hoc analysis revealed that the mean values of serum cystatin $\mathrm{C}$, creatinine and uric acid were significantly higher in patients with pre-eclampsia when compared to healthy pregnant women.

Table 1: Maternal \& child characteristics in the study groups, MediCiti Institute of Medical Sciences, Hyderabad, 2012.

\begin{tabular}{|c|c|c|c|c|c|c|c|c|c|c|}
\hline \multirow[t]{2}{*}{ Parameters } & \multicolumn{3}{|c|}{ Healthy controls $(n=69)$} & \multicolumn{3}{|c|}{ PIH (n=27) } & \multicolumn{4}{|c|}{ Pre-eclampsia ( $\mathrm{n}=20$ ) } \\
\hline & $\begin{array}{l}\text { Mean } \\
\text { (SD) }\end{array}$ & $95 \% \mathrm{CI}$ & $\mathbf{N}(\%)$ & $\begin{array}{l}\text { Mean } \\
\text { (SD) }\end{array}$ & $95 \% \mathrm{CI}$ & $\mathbf{N}(\%)$ & $\begin{array}{l}\text { Mean } \\
\text { (SD) }\end{array}$ & $95 \% \mathrm{CI}$ & $\mathbf{N}(\%)$ & $P$ value \\
\hline $\begin{array}{l}\text { Age } \\
\text { (Years) }\end{array}$ & $\begin{array}{l}21.6 \\
(2.5)\end{array}$ & $\begin{array}{l}20.9 \text { to } \\
22.2\end{array}$ & & $\begin{array}{l}21.4 \\
(2.2)\end{array}$ & $\begin{array}{l}20.5 \text { to } \\
22.3\end{array}$ & & $\begin{array}{l}21.1 \\
(1.9)\end{array}$ & $\begin{array}{l}20.2 \text { to } \\
22.0\end{array}$ & & 0.75 \\
\hline $\begin{array}{l}\text { Height } \\
(\mathrm{cm})\end{array}$ & $\begin{array}{l}153.0 \\
(5.5)\end{array}$ & $\begin{array}{l}151.6 \text { to } \\
154.5\end{array}$ & & $\begin{array}{l}152.8 \\
(5.3)\end{array}$ & $\begin{array}{l}150.5 \text { to } \\
155.1\end{array}$ & & $\begin{array}{l}154.4 \\
(5.9)\end{array}$ & $\begin{array}{l}151.4 \text { to } \\
157.4\end{array}$ & & 0.61 \\
\hline $\begin{array}{l}\text { Weight } \\
\text { (Kg) }\end{array}$ & $\begin{array}{c}54.3 \\
(9.3)\end{array}$ & $\begin{array}{l}51.9 \text { to } \\
56.7\end{array}$ & & $\begin{array}{l}57.6 \\
(9.2)\end{array}$ & $\begin{array}{l}53.8 \text { to } \\
61.4\end{array}$ & & $\begin{array}{l}57.9 \\
(7.7)\end{array}$ & $\begin{array}{l}54.2 \text { to } \\
61.6\end{array}$ & & 0.16 \\
\hline BMI & $\begin{array}{l}22.9 \\
(2.8)\end{array}$ & $\begin{array}{l}22.1 \text { to } \\
23.6\end{array}$ & & $\begin{array}{l}25.0 \\
(3.3)\end{array}$ & $\begin{array}{l}23.6 \text { to } \\
26.4\end{array}$ & & $\begin{array}{l}24.2 \\
(2.6)\end{array}$ & $\begin{array}{l}22.8 \text { to } \\
25.5\end{array}$ & & $0.01 *$ \\
\hline $\begin{array}{l}\text { Systolic } \\
\text { blood } \\
\text { pressure } \\
\text { (mmHg) }\end{array}$ & $\begin{array}{l}114.1 \\
(8.9)\end{array}$ & $\begin{array}{l}112.0 \text { to } \\
116.3\end{array}$ & & $\begin{array}{l}150.7 \\
(9.1)\end{array}$ & $\begin{array}{l}147.1 \text { to } \\
154.3\end{array}$ & & $\begin{array}{l}162.0 \\
(14.7)\end{array}$ & $\begin{array}{l}155.1 \text { to } \\
168.8\end{array}$ & & $<0.001 *$ \\
\hline $\begin{array}{l}\text { Diastolic } \\
\text { blood } \\
\text { pressure } \\
(\mathrm{mmHg})\end{array}$ & $\begin{array}{l}77.7 \\
(7.6)\end{array}$ & $\begin{array}{l}75.9 \text { to } \\
79.6\end{array}$ & & $\begin{array}{l}101.1 \\
(8.0)\end{array}$ & $\begin{array}{l}97.9 \text { to } \\
104.2\end{array}$ & & $\begin{array}{l}106.0 \\
(6.8)\end{array}$ & $\begin{array}{l}102.8 \text { to } \\
109.1\end{array}$ & & $<0.001 *$ \\
\hline $\begin{array}{l}\text { Primigravi } \\
\text { da }(\%)\end{array}$ & & & $38(55.1)$ & & & $18(66.7)$ & & & $16(80)$ & 0.13 \\
\hline $\begin{array}{l}\text { Mode of } \\
\text { delivery }\end{array}$ & & & & & & & & & & $0.02 *$ \\
\hline $\begin{array}{l}\text { Normal } \\
\text { vaginal } \\
\text { delivery }\end{array}$ & & & $45(65.2)$ & & & $17(62.9)$ & & & $8(40)$ & \\
\hline $\begin{array}{l}\text { Instrument } \\
\text { al delivery }\end{array}$ & & & $11(15.9)$ & & & $3(11.1)$ & & & $3(15)$ & \\
\hline $\begin{array}{l}\text { LSCS } \\
\text { emergency }\end{array}$ & & & $10(14.4)$ & & & $5(18.5)$ & & & $9(45)$ & \\
\hline $\begin{array}{l}\text { LSCS } \\
\text { elective }\end{array}$ & & & $3(4.3)$ & & & $2(7.4)$ & & & $0(0)$ & \\
\hline $\begin{array}{l}\text { Urine } \\
\text { proteins }\end{array}$ & & & & & & & & & & $<0.001 *$ \\
\hline Nil & & & $67(97.1)$ & & & $6(22.2)$ & & & $1(5)$ & \\
\hline Trace & & & $2(2.8)$ & & & $21(77.7)$ & & & $1(5)$ & \\
\hline $1+$ & & & $0(0)$ & & & $0(0)$ & & & $12(60)$ & \\
\hline $2+$ & & & $0(0)$ & & & $0(0)$ & & & $6(30)$ & \\
\hline $\begin{array}{l}3+\text { and } \\
\text { above }\end{array}$ & & & $0(0)$ & & & $0(0)$ & & & $0(0)$ & \\
\hline $\begin{array}{l}\text { Gestational } \\
\text { age of } \\
\text { delivery } \\
\text { (weeks) }\end{array}$ & $\begin{array}{l}38.7 \\
(1.5)\end{array}$ & $\begin{array}{l}38.3 \text { to } \\
39.1\end{array}$ & & $\begin{array}{l}38.1 \\
(1.4)\end{array}$ & $\begin{array}{l}37.5 \text { to } \\
38.7\end{array}$ & & $\begin{array}{l}36.9 \\
(4.0)\end{array}$ & $\begin{array}{l}35.0 \text { to } \\
38.8\end{array}$ & & $0.007 *$ \\
\hline $\begin{array}{l}\text { Birth } \\
\text { Weight } \\
(\text { Kg) }\end{array}$ & $\begin{array}{l}2.7 \\
(0.4)\end{array}$ & $\begin{array}{l}2.6 \text { to } \\
2.8\end{array}$ & & $\begin{array}{l}2.6 \\
(0.4)\end{array}$ & $\begin{array}{l}2.4 \text { to } \\
2.8\end{array}$ & & $\begin{array}{l}2.3 \\
(0.8)\end{array}$ & $\begin{array}{l}2.0 \text { to } \\
2.7\end{array}$ & & $0.02 *$ \\
\hline
\end{tabular}


ROC curves ${ }^{24}$ were used to compare the diagnostic potential of serum cystatin $\mathrm{C}$, creatinine and uric acid as renal markers in hypertensive disorders of pregnancy. It shows that serum creatinine had a superior diagnostic accuracy for preeclampsia compared to that of serum uric acid or serum cystatin $\mathrm{C}$ and that the diagnostic accuracy of serum uric acid was better than that of serum cystatin C (Table: 3, fig: 1). There was no difference in the AUC between the three markers in those who developed PIH.

Table 2: Mean values of S-cystatin C, S-creatinine and S-uric acid in the study groups, MediCiti Institute of Medical Sciences, Hyderabad, 2012.

\begin{tabular}{|c|c|c|c|c|c|c|c|}
\hline \multirow[t]{2}{*}{ Parameters } & \multicolumn{2}{|c|}{ Healthy controls ( $n=69)$} & \multicolumn{2}{|l|}{ PIH (n=27) } & \multicolumn{2}{|c|}{ Pre-eclampsia $(\mathrm{n}=20)$} & \multirow[t]{2}{*}{ P value } \\
\hline & Mean (SD) & $95 \% \mathrm{CI}$ & Mean (SD) & $95 \% \mathrm{CI}$ & Mean (SD) & $95 \% \mathrm{CI}$ & \\
\hline $\begin{array}{l}\text { Serum cystatin } \\
\mathrm{C}(\mathrm{mg} / \mathrm{L})\end{array}$ & $1.06(0.2)$ & 1.01 to 1.12 & $1.25(0.9)$ & 0.86 to 1.64 & $1.47(0.9)$ & 1.01 to 1.92 & $0.04 *$ \\
\hline $\begin{array}{l}\text { Serum } \\
\text { creatinine } \\
(\mathbf{m g} / \mathrm{dl})\end{array}$ & $0.67(0.1)$ & 0.64 to 0.69 & $0.67(0.14)$ & 0.62 to 0.73 & $0.95(0.2)$ & 0.82 to 1.08 & $<0.001 *$ \\
\hline $\begin{array}{l}\text { Serum uric acid } \\
(\mathrm{mg} / \mathrm{dl})\end{array}$ & $4.28(1.1)$ & 4.00 to 4.57 & $4.30(1.0)$ & 3.87 to 4.72 & $6.13(1.8)$ & 5.26 to 7.00 & $<0.001 *$ \\
\hline
\end{tabular}

Table 3: ROC analysis of renal markers in hypertensive disorders of pregnancy, MediCiti Institute of Medical Sciences, Hyderabad, 2012.

\begin{tabular}{|c|c|c|c|c|c|c|c|c|c|c|}
\hline \multicolumn{6}{|c|}{ PIH } & \multicolumn{5}{|c|}{ Pre-eclampsia } \\
\hline & $\begin{array}{l}\text { AUC } \\
(95 \% \mathrm{CI})\end{array}$ & Sensitivity & Specificity & $+\mathbf{L R}$ & -LR & $\begin{array}{l}\text { AUC } \\
(95 \% \mathrm{CI})\end{array}$ & Sensitivity & Specificity & $+\mathrm{LR}$ & -LR \\
\hline $\begin{array}{l}\text { Serum } \\
\text { cystatin } C \\
(\mathrm{mg} / \mathrm{L})\end{array}$ & $\begin{array}{l}0.50 \\
(0.39 \text { to } \\
0.60)\end{array}$ & 66.67 & 44.93 & 1.21 & 0.74 & $\begin{array}{l}0.65 \\
(0.54- \\
0.75)\end{array}$ & 50.0 & 87.0 & 3.83 & 0.58 \\
\hline $\begin{array}{l}\text { Serum } \\
\text { creatinine } \\
(\mathrm{mg} / \mathrm{dl})\end{array}$ & $\begin{array}{l}0.51 \\
(0.41 \text { to } \\
0.62)\end{array}$ & 22.22 & 92.75 & 3.07 & 0.84 & $\begin{array}{l}0.85 \\
(0.76- \\
0.91)\end{array}$ & 65.0 & 97.1 & 22.42 & 0.36 \\
\hline $\begin{array}{l}\text { Serum } \\
\text { uric acid } \\
\text { (mg/dl) }\end{array}$ & $\begin{array}{l}0.53 \\
(0.42 \text { to } \\
0.63)\end{array}$ & 74.07 & 42.03 & 1.28 & 0.62 & $\begin{array}{l}0.80 \\
(0.70- \\
0.88)\end{array}$ & 75.0 & 76.8 & 3.23 & 0.33 \\
\hline
\end{tabular}

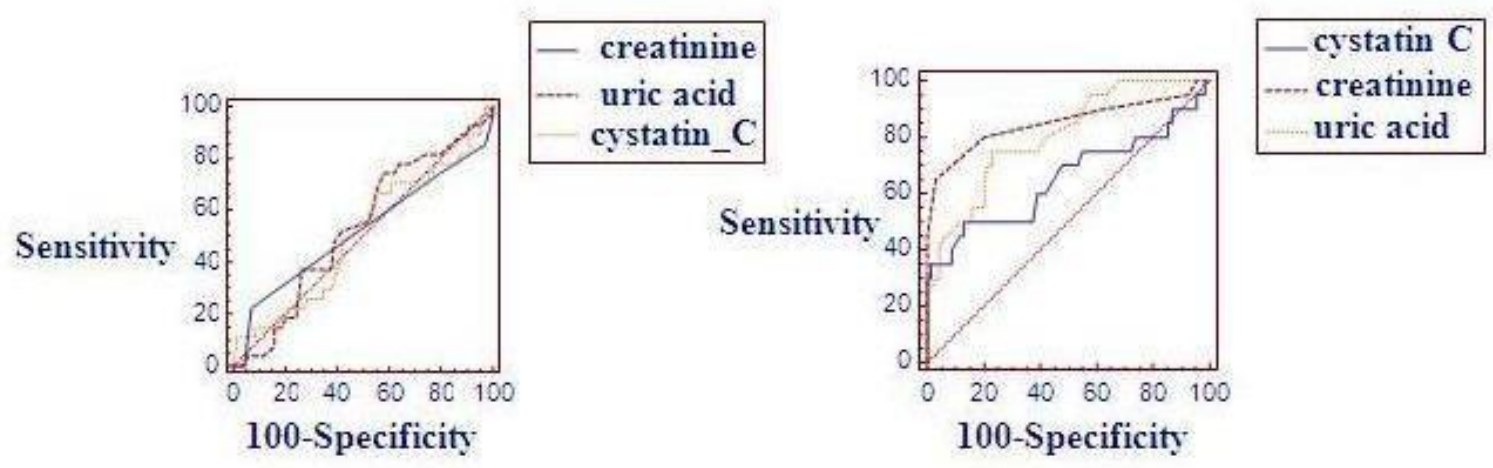

Figure 1: Comparison of ROC curves for serum creatinine, serum uric acid and serum cystatin C in PIH and preeclampsia respectively. 

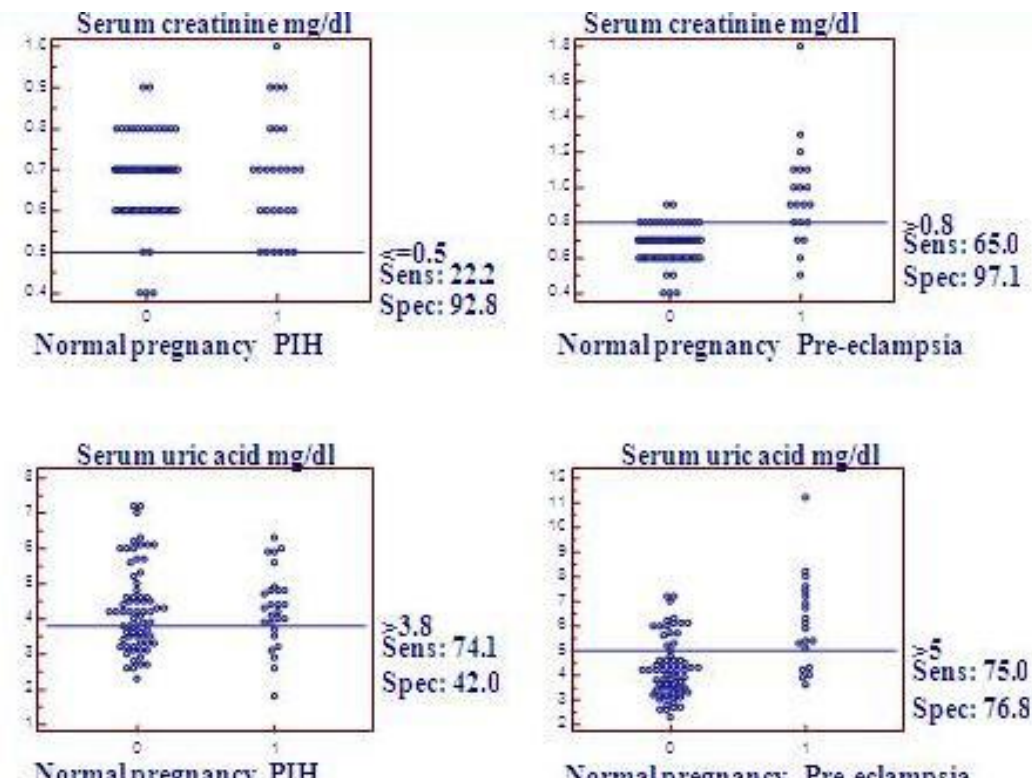

Normal pregnancy PIH

Normalpregnanç Pre-eclampsia
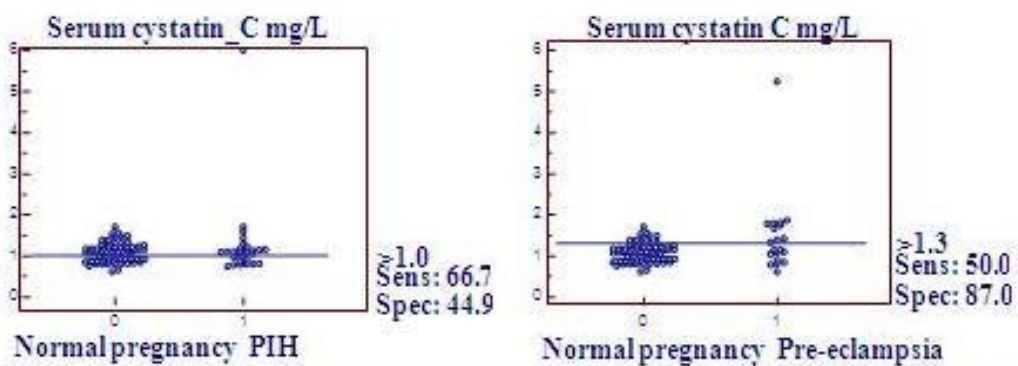

Figure 2: Levels of serum cystatin C, serum creatinine and serum uric acid in preeclampsia and normal pregnancy, in PIH and normal pregnancy given in $\mathrm{mg} / \mathrm{L}$ and $\mathrm{mg} / \mathrm{dL}$ respectively, with calculated cut-off levels for maximal sensitivity and specificity.

\section{DISCUSSION}

The renal dysfunction occurring in hypertensive disorders of pregnancy can be due to hemodynamic changes, ${ }^{12}$ glomerular endotheliosis, ${ }^{25}$ as well as podocyte damage. ${ }^{26}$ It is characterized by a decline in GFR, the values of which can be above normally expected values in healthy non-pregnant women due to altered hemodynamics in pregnancy. It is therefore necessary to closely monitor renal function so that prompt therapy can be implemented in order to prevent further renal damage. The most widely used markers of renal function in women with hypertensive disorders are serum concentrations of cystatin $\mathrm{C}$, creatinine and uric acid.

Several international studies have been done on serum cystatin $\mathrm{C}$ levels in normal pregnancy and preeclampsia. ${ }^{10,11,12,13,14,27,28}$ Serum cystatin $C$ is a marker for glomerular filtration rate (GFR) in non pregnant healthy women below 50 years of age ${ }^{29}$ and also during pregnancy. $^{30,31}$ Although glomerular filtration rate, defined as the plasma clearance of low molecular weight substances, is normally increased during pregnancy ${ }^{32,33}$ expecting a decrease in serum cystatin $\mathrm{C}$, it does not normally decrease during pregnancy. This might be due to increased production of cystatin $\mathrm{C}$ during pregnancy due to an increased number of nucleated cells. We have found significantly elevated levels of serum cystatin $C$ in twin pregnancies, which could support this theory. ${ }^{10,34}$ Another explanation might be that the filtration of cystatin C, a positively charged 13,343- Da molecule might be different ${ }^{10}$ due to some physiological or abnormal renal process in pregnancy. In the present study there was a statistically significant difference in the mean values of serum cystatin $C$ between the three study groups $(p<0.04)$ and the results were consistent with the previous studies. $10,11,14,35$

Serum creatinine is widely used as an indicator for GFR. Our study revealed that there was a statistically significant difference in the mean values of serum creatinine $(1 \mathrm{mg} / \mathrm{dl}=88.4 \mathrm{umol} / \mathrm{L})$ between the three study groups $(p<0.001)$. There was a significant increase in serum creatinine in pre-eclamptic patients in comparison with healthy controls in our study and were consistent with the previous studies. ${ }^{10,11,14,35}$ We did not observe any significant increase in serum creatinine in those who developed PIH in comparison with healthy controls and the results were inconsistent with only one study. ${ }^{11}$ 
Uric acid is a catabolic product of endogenous and dietary nucleic acids. It is freely filtered through the glomerular membrane and then almost completely reabsorbed in the proximal tubuli. It is also actively secreted in the distal tubuli. Increased uric acid level is a key clinical feature of preeclampsia. Higher levels correlate with significant maternal and fetal morbidity and mortality and is shown to be useful as a predictor for fetal outcome in preeclampsia. $^{36,37}$ In the present study there was a statistically significant difference in the mean values of serum uric acid $(1 \mathrm{mg} / \mathrm{dl}=59.48 \mu \mathrm{mol} / \mathrm{L})$ between the three study groups $(\mathrm{p}<0.001)$. There was a significant increase in serum uric acid in pre-eclamptic patients in comparison with healthy controls in our study and were consistent with the previous studies. ${ }^{10,11,14,35}$ We did not observe any significant increase in serum uric acid in those who developed PIH in comparison with healthy controls and the results were inconsistent with only one study. ${ }^{11}$

In Conclusion the data of the present investigation demonstrates that the three serum markers are increased in PE in comparison with healthy controls at the end of pregnancy. In PIH there was an increase in serum cystatin $\mathrm{C}$ but not serum creatinine and serum uric acid. ROC analysis showed that that serum creatinine had a superior diagnostic accuracy for preeclampsia compared to that of serum uric acid or serum cystatin $\mathrm{C}$ and that the diagnostic accuracy of serum uric acid was better than that of serum cystatin $\mathrm{C}$. The diagnostic accuracy of these markers is not much helpful in PIH. Our study is limited by its sample size with limited number of patients in the study groups (PIH, PE).

Measurement of these markers with their associated GFR early in pregnancy would be helpful in identification of patients at high risk of developing $\mathrm{PIH} / \mathrm{PE}$ and its complications. ${ }^{13,38,39}$ Which renal markers, individually or in combination, measured during early pregnancy will identify patients at high risk for developing PIH/PE needs to be investigated.

\section{ACKNOWLEDGEMENTS}

We wish to thank the Fogarty-supported SHARE INDIA team for conducting the research method courses which contributed to conduct and publish this research work. Research reported in this publication was conducted by scholars in the Fogarty International Center of the National Institutes of Health training program under Award Number D43 TW 009078. The content is solely the responsibility of the authors and does not necessarily represent the official views of the National Institutes of Health.

We would also like to thank Dr Satyanarayana, Dr Akshay Mishra and Dr Sashidar for their contributions in data collection, data analysis and writing the protocol respectively. We are very grateful to the nursing staff of the department of Obstetrics \& Gynecology, laboratory technicians for their help in collecting and storing the samples.
Funding: This study was supported by the management of Mediciti Institute of Medical Sciences and partly by ICMR short term studentship (STS) program

Conflicts of interest: None declared

Ethical approval: The study has been approved by the Institute's ethical committee

\section{REFERENCES}

1. Roberts JM, Gammill HS. Preeclampsia: Recent insights. Hypertension. Dec 2005; 46960:1243-1249.

2. Zhang J, Meikle S, Trumble A. Severe maternal morbidity associated with hypertensive disorders in pregnancy in the United States. Hypertens Pregnancy. 2003; 22(20):203-212.

3. Kingdom J, C P, Jauniaux ERM Shaughn O'Brien P.M. The Placenta: Basic Science and Clinical Practice(RCOG-Press, London) 2000; Vol.1.

4. Khong TY, De Wolf F, Robertson WB, Brosens I. Inadequate maternal vascular response to placentation in pregnancies complicated by preeclampsia and by small-for-gestational age infants. Br J Obstet Gynaecol. 1986; 93(10):1049-1059.

5. Pijnenborg R, Anthony J, Davey DA, et al. Placental bed spiral arteries in the hypertensive disorders of pregnancy. Br J Obstet Gynaecol 1991; 98(7):648-655.

6. Meekins JW, Pijnenborg R, Hanssens M, McFadyen IR, VanAsshe A. A study of placental bed spiral arteries and trophoblast invasion in normal and severe pre-eclamptic pregnancies. $\mathrm{Br} \mathrm{J}$ Obstet Gynaecol. 1994; 101(8):669-674.

7. Brosens JJ, Pijnenborg R, Brosens IA. The myometrial junctional zone spiral arteries in normal and abnormal pregnancies: a review of the literature. Am J Obstet Gynaecol . 2002; 187(5):1416-1423.

8. Newman DJ, Thakkar H, Edwards RG, Wilkie M, White T, Grubb AO, Price CP. Serum cystatin C measured by automated immunoassay: a more sensitive marker of changes in GFR than serum creatinine. Kidney Int 1995; 47: 312-8.

9. Jung K, Jung M. Cystatin C: a promising marker of glomerular filtration rate to replace creatinine. Nephron 1995; 70: 370-1.

10. H. Strevens, D. Wide-swensson \& A. Grubb. Serum cystatin $\mathrm{C}$ is a better marker for preeclampsia than serum creatinine or serum urate. Scand J Clin Lab Invest 2001; 61: 575-580

11. H. Strevens, D. Wide-swensson \& A. Grubb, A. Hansen, T. Horn, I. Ingemarsson, S. Larsen, J R. Nyengaard, O. Torffvit, J. Willner, S. Olsen. Serum cystatin C reflects glomerular endotheliosis in normal, hypertensive and pre-eclamptic pregnancies. BJOG: an international journal of Obstetrics and Gynaecology september 2003, Vol. 110, pp. 825-830.

12. N. Franceschini, C. Qiu, D A. Barrow, M A. Williams. Cystatin C and Preeclampsia: A Case Control Study. Renal Failure, 30:89-95, 2008.

13. B. Thilaganathan, E. Ralph, Aris T. Papageorghiou, K. Melchiorre, J. Sheldon. Raised maternal cystatin 
C: An early pregnancy marker for pre-eclampsia. Reproductive sciences, Vol. 16 No. 8 August 2009.

14. Novakov Mikic A, Cabarkapa V, Nikolic A, Maric D, Brkic S, Mitic G, Ristic M, Stosic Z. Cystatin C in pre-eclampsia. J Matern Fetal Neonatal Med.2012 Jul;25(7):961-5.

15. Brown MA, Lindheimer MD, de Sweit M, VanAssche A, Mountquin JM. The classification and diagnosis of the hypertensive disorders of pregnancy: statement from the international society for the study of hypertension in pregnancy (ISSHP). Hypertens pregnancy. 2001; 20(1):IX-XIV

16. National committee for clinical laboratory standards. Procedures for the collection of diagnostic blood specimens by venipuncture: Approved standard H3 A4. $4^{\text {th }}$ ed. Wayne PA: National committee for clinical laboratory standards, 1998.

17. National committee for clinical laboratory standards. Procedures for the handling and transport of domestic diagnostic blood specimens and etiologic agents: Approved standard H5 - A3 ${ }^{3 \mathrm{rd}}$ ed. Wayne PA: National committee for clinical laboratory standards, 1994.

18. Hazel Finney, David J. Newman, Walter Gruber, Peter Merle, and Christopher P. Price. Initial evaluation of cystatin $\mathrm{C}$ measurement by particleenhanced immunonephelometry on the Behring nephelometer systems (BNA, BN II). Clinical Chemistry. 1997; 43(6):1016-1022.

19. Larsen K. Creatinine assay by a reaction-kinetic approach. Clin Chem Acta. 1972; 41:209-217.

20. Knapp ML, Mayne, PD. Development of an automated kinetic jaffe method designed to minimize bilirubin interference in plasma creatinine assays. Clin Chem Acta. 1987; 168:239-246.

21. Bulgar HA, Johns HE. The determination of plasma uric acid, J Biol Chem 1941;140:427.

22. Kalckan HM. Differential spectrophotometry of purine compounds by means of specific enzymes, J Biol Chem 1947;167:429

23. Yoder, J.Adams, E.C.,and Free. H.M.: Simultaneous screening for urinary Occult blood, Protein, Glucose and pH. Amer.J. Med Tech.31:285;(1965).

24. Zweig MH, Campbell G. Receiver-operating characteristic (ROC) plots: a fundamental evaluation tool in clinical medicine. Clin Chem 1993; 39: 561-77.

25. Lafayette RA, Druzin M, Sibley R, Derby G, Malik $\mathrm{T}$, Huie P, Polhemus C, et al.Nature of glomerular dysfunction in pre-eclampsia. Kidney Int 1998; 54: 1240-1249.

26. Garovic VD, Wagner SJ, Turner ST, Rosenthal DW, Watson WJ, Brost $\mathrm{BC}$, Rose $\mathrm{CH}$, et al. Urinary podocyte excretion as a marker for pre-eclampsia. AM J ObstetGynecol 2007; 196: 320.e1-320.e7.

27. Babay Z, Al-Wakeel J, Addar M, Mittwalli A, Tarif N, Hammad D, Ali N, Al-Askar A, Choudhary AR.
Serum cystatin $\mathrm{C}$ in pregnant women: reference values, reliable and superior diagnostic accuracy. Clin Exp Obstet Gynecol. 2005; 32 (3):175-9.

28. Fang Guiying, Zhou Changhao, Zhang HongZhen et al. The significance of cystatin $\mathrm{C}$ measurement in patients with preeclampsia-eclampsia. Progress In Obstetrics and Gynecology, 2005-03.

29. Norlund L, Fex G, Lanke J, von Schenck H, Nilsson JE, Leksell H, Grubb A. Reference intervals for the glomerular filtration rate and cellular proliferation markers: serum cystatin $\mathrm{C}$ and serum b2-microglobulin-cystatin C-ratio. Scand J Clin Lab Invest 1997; 57: 463-70.

30. Cataldi L, Mussap M, Bertelli L, et al. Cystatin C in healthy women at term pregnancy and in their infant newborns: relationship between maternal and neonatal serum levels and reference values. Am J Perinatol 1995; 16: 287-95.

31. H. Strevens, D. Wide-swensson, O. Torffvit, A. Grubb. Serum cystatin C for assessment of glomerular flitration rate in pregnant and non pregnant women. Indications of altered filtration process in pregnancy. Scand J Clin Lab Invest 2001;62(2): 141-147.

32. Dunlop W. Serial changes in renal haemodynamics during normal human pregnancy. $\mathrm{Br} \mathrm{J}$ Obstet Gynaecol 1981; 88: 1-9.

33. Chapman AB, Abraham WT, Zamudio S, et al. Temporal relationships between hormonal and haemodynamic changes in early human pregnancy. Kidney Int 1998; 54: 2056-2063.

34. Akbari A.(2004) Glomerular endotheliosisin normal pregnancy and pre-eclampsia. Br J ObstedGynecol 111,192

35. Kristensen K, Wide-swensson D, Schmidt C, Blirup-jensen S, Lindstrom V, Strevens H \& Grubb A. Cystatin C, B2 microglobulin and $B$-trace protein in pre-eclampsia. Acta Obstetricia et Gynecologica. 2007; 86: 921- 926.

36. Sagen N, Haram K, Nilsen ST. Serum urate as a predictor of fetal outcome in severe pre-eclampsia. Acta Obstet Gynecol Scand 1984; 63: 71-5.

37. Schuster E, Weppelman B. Plasma urate measurements and fetal outcome in preeclampsia. Gynecol 39: 561-77. Obstet Invest 1981; 12: 162-7.

38. Fabrício da Silva Costa, Padma Murthi, Rosemary Keogh, Nicole Woodrow. Early screening for preeclampsia. Rev. Bras. Ginecol. Obstet. vol.33 no.11 Rio de Janeiro Nov. 2011.

39. Karl Kristensen, I. Larsson and S.R. Hansson. Increased cystatin $\mathrm{C}$ expression in the pre-eclamptic placenta. Molecular Human Reproduction 2007;13(3):189-195.

DOI: $10.5455 / 2320-1770 . i j r \operatorname{cog} 20131205$

Cite this article as: Padma Y, Aparna VB,

Kalpana B, Ritika V, Sudhakar PR. Renal markers in normal and hypertensive disorders of pregnancy in Indian women: a pilot study. Int J Reprod Contracept Obstet Gynecol 2013;2:514-20. 